\title{
Social and Environmental Disclosures and Holistic Growth in the Positive Accounting Theory (PAT) View
}

\author{
Osifo, I. U. Osagie ${ }^{1}$ and Fasua, Henry Kehinde ${ }^{2}$ \\ Department of Accounting, Faculty of Management Sciences, University of Benin, Benin City, Nigeria. \\ osifosagie@gmail.com ${ }^{1}$ and fasua.henryfash7@ gmail.com ${ }^{2}$
}

\begin{abstract}
The objective of this study is to examine corporate social and environmental disclosure and holistic growth in the Positive Accounting Theory (PAT) view. Specifically, the paper investigates the relationship that exists between corporate social responsibility and Return on asset, leverage, and firm size. The data for this study were obtained from secondary source which were collected from the audited annual reports as well as accounts of the listed Deposit Money Banks in Nigeria. The paper is descriptive and highly empirical as it embraces the use of panel regression technique as tool of analysis. The regression analysis shows that corporate social and environmental is associated with: ROA, firm' size, and leverage. Therefore, the outcomes confirm positive relationship between support the bonus plan hypothesis and political cost hypothesis, while association with debt/equity hypothesis is negative. The study recommends effective disclosure of corporate social responsibility as one of factors that brings about holistic growth.
\end{abstract}

Keywords: Corporate Social and Environmental Disclosure, Positive Accounting Theory, Bonus Plan Hypothesis, Debt/Equity Hypothesis, Political Cost Hypothesis

\section{Introduction}

The growth and development of a firm can be traced to its original mission as well as focus of its promoters. Decision determines destiny and foundation of a building has more to tell about its owner's plan and futuristic desire of the owners. For a firm to accomplish its mission, it depends on its blueprint and its responsibility to its immediate environment - micro and macro environments. These have something to do with its mission and mechanism to acquire competitive advantage over others. In as much no firm or individual can exist without its environment. Therefore, it is imperative to research into social and environmental disclosure and holistic growth.

From existing literature, there are different schools of thought regard firm's responsibility and obligation to its micro environment and macro environment. Pristine capitalist school of thought believes that the only responsibility and duty of a firm is to maximize shareholder wealth and make profit. Expedient school of thought asserts that the main purpose of existence of a firm is to maximize the wealth of shareholders. Proponent of the social contract school of thought believes that a firm and other firms grow up at the will of environment, thus it has responsibility and duty to react to the demands of society. Social ecologists believe that a firm creates environmental problems in attempting to maximize the wealth of its shareholders; therefore it should be responsible for providing solutions. Socialist school of thought holds that a firm needs to readjust its ownership of assets and structure of society (Gray, Owen \& Adams, 1996; Gray, Javad , Power \& Sinclair, 2001; ICAN, 2014).

Therefore, this paper is motivated to examine prenatal mission of corporate firm and holistic growth as it relates to the relationship between corporate social responsibility and holistic growth in Nigerian banking sector. However, from available write-up there are conflicting conclusions. For instance, Olayinka and Temitope (2011) prove that there is a positive association between profitability of firm and corporate social responsibility expenditure (Amole, Adebiyi, \& Awolaja, 2012). In the same vein, Christina and Zuaini (2012) carried out a research in Malaysia to evaluate the impact of firm size, leverage and ROA on corporate social responsibility and found out they have positive relationship with corporate social and environmental disclosure.

However, Servaes and Tamayo (2013) concluded that there is no direct association between corporate social responsibility and firm value. In research work carried out by Stefan, Georgeta and Diana (2015) on relationship between corporate social responsibility ratings and companies value using a multivariate model, discovered that firm size as well as leverage have a negative relationship with corporate social responsibility.

Besides, most of these studies were carried out in developed countries but only few studies have been done in Nigeria, such as the work carried out by Musa (2010). Apart from this, it was also discovered that most research works failed to agree as a result of some methodological deficiencies. On this platform, this paper seeks to research into social and environmental disclosure and holistic growth taking into account positive accounting as an underpinning theory in a developing country like Nigeria. This study shall offer answers to the following research questions: what is the relationship between firm size and corporate social responsibility? What is the 
association between leverage and corporate social responsibility? Is there a significant relationship between return on asset and corporate social responsibility?

The broad objective of this study is to evaluate social and environmental disclosure and holistic growth in Nigeria using positive accounting theory as theoretical framework while the specific objectives are: to determine if there is a relationship between firm size and corporate social responsibility; to ascertain the association between leverage and corporate social responsibility and to find out if there is a relationship between return on asset and corporate social responsibility. In order to appeal to empirical evidence data shall be collected from the Nigeria stock market for the year 2013. This study will be of importance to the shareholders, potential investors and Nigeria companies at large premised on the fact that it will serve as a awaken call to various companies to appreciate the need as well as the importance of engaging in corporate social responsibility practices.

\subsubsection{Corporate social responsibility}

\section{Literature Review}

Corporate social responsibility entails communicating the social effect of organizations economic actions to a certain interest group within the society. The development of these practices date back to the early and mid 1990's as the reporting practices became wide spread the disclosure made by some organizations became more extensive (Deegan, 2007; Deegan \& Gordon, 1996). Most recently, the prominence of corporate social responsibility reporting which deals simultaneously with the economic, environmental and social dimension of corporate performance has been given priority (KPMG, 2005). Business firms which engage in social responsibility practice incur more cost because they regard corporate social responsibility as a public relation stunt used by large corporation to look good in front of customers and other stakeholders (Ajide \& Adetunji, 2014)

In 2011, the oil and gas sector spent 9.5 billion on corporate social responsibility followed by telecoms which amounted to 6.4 billion as well as the banking industry which came third in the position with the sum of 1.869 billion sent by eight banks in Nigeria in 2012 on various community related project under corporate social responsibility to identify with the society in which they operate (Obi, 2013). Nigeria companies have been perceived to practice corporate social responsibility as corporate philanthropy aimed at addressing social economic development challenges holding to the fact that corporate social responsibility is still at an elementary stage in Nigeria (Obi, 2013). In view of huge cost incurred by companies in Nigeria annually on corporate social responsibility, it has been viewed that corporate social responsibility could increase profit (Ajide \& Adetunji, 2014). Also aggressive corporate social responsibility activities could aid companies profit in gaining a possible listing in the stock market this in turn could enhance the company's stock price therefore making executives stock and stock option more profitable(Robins, 2011).

Most organizations are expected to be responsible to their clients as well as their immediate environment and society as a whole. Corporate social responsibility is a critical way for firms to communicate with society to win the minds of the public that are meeting their social expectations (Branco \& Rodrigues, 2008). The concept of corporate social responsibility (CSR) refers to the universal opinion held by researchers, by a raising number of ethical professionals and citizens that modern business have obligations to society that extends beyond the responsibilities to the stakeholders or investors of the firm (Visser, Matten, Pohl, \& Tolhurust, 2010).

According to the European commission (2006) CSR can be defined as a concept whereby companies integrate social and environmental concerns in their business operations and in their interaction with their stakeholders on a voluntary basis. CSR conceptually can be described as an obligation, beyond that required by the law and economics for a firm to pursue long term goals that are good for society. Maigana and Ferrell, (2004) describe CSR as an instrument to increase firms' legitimacy in the eyes of their stakeholders and to develop positive social responsibility images to burnish their reputations.

\subsubsection{Firm size and corporate social responsibility}

Large firms are more politically sensitive than small firms and face differential incentives in their choice of accountability procedures that leads them to defer reported earnings from current to future periods (Watts\& Zimmerman, 1986). Hence under political cost hypothesis, managers consider that as they are under a great deal of political cost hypothesis, scrutiny and public pressure, this could motivate them to disclose social reporting. Ness and Mirza (1991) argue that the larger the firm the more chance it is to disclose social responsibility. Cormier and Magnan (2003) also found a positive relationship between firm size and corporate social responsibility (Magnan, Nadeau \& Cormier, 1999).

Belkaoui and Karpik (1989) examined the association between the decision of firms to disclose corporate social responsibility information and economic performance in their research work. They found out that corporate social responsibility correlated with firms that are perceived to be responsive socially. In 
Indonesia, Sarumpaet (2005) examines the relationship between environmental performance and financial performance and then argues that, firm invests in more environmentally friendly technology and management.

H1: Firm's size is positively associated with corporate social and environmental disclosure level.

\subsubsection{Leverage and Corporate Social Responsibility}

Debt financing could impact on the level of disclosure of a firm, the higher the debt employed by a firm the more likely managers use an accounting method that boost the income level of the organization. It has been argued that when a firm is making a large use of debt, a monitoring problem arise between stockholder and creditors thus voluntary disclosure can be expected to increase with leverage.

Positive accounting sees risk as an important role in decision making. Companies which disclose less information or information with poor quality relative to other companies of similar size and risk characteristic are perceived by lenders as being secretive and less forth coming in disclosing information useful for decision purpose and thus are considered more risky (Christina \& Zuaini, 2012). Also higher level of disclosure is argued to lead to lower cost of debt capital (Hibbit, 2003). It therefore implies that if a firm has entered into agreement with lenders, and these agreement involves accounting- based debt covenants, then the managers have an incentive to adopt accounting method that relax the potential impact of the constraints (Deegan \& Unerman, 2005). Therefore it can be observed more increase in corporate social responsibility disclosure could lead to the possibility that debt ratio will increase (Banwarie, 2011).

Prior studies indicates that a positive relationship exist between leverage and corporate social responsibility. In an attempt to avoid any hurdle of the debt convents, management is said to choose accounting method that increase the current periods reported earnings for example by reducing discretionary social and environmental programs or by not engaging in any program which reduce reported earnings in the short term (Hibbit, 2003). Orij (2007) carried out a study on corporate social responsibility and found out that a positive relationship exist between corporate social responsibility and leverage.

Belkoui and Karpik(1989) found a negative relationship between leverage and corporate social responsibility disclosure level. They are of the view that firms with a high leverage must adhere to strict debt covenant which in turn as every tendency of reducing their ability to spend resources on corporate social responsibility as well as disclose information about corporate social responsibility. Based on the above statement the following hypothesis is proposed.

\section{H2: Firms leverage is positively associated with corporate social responsibility disclosure level}

\subsubsection{Bonus Plan and Corporate Social Responsibility}

The bonus plan hypothesis states that a manager of firm with bonus plan is more likely to use accounting techniques that increase current period reported income. In area of corporate social responsibility, scholars have discovered a positive association between the social and environmental disclosure, and bonus plan. For instance, Chan and Kent (2003) researched on the relationship between return on asset and social disclosure and discovered that it has a positive outcome. Robert (1992) worked on determinants of corporate social responsibility disclosure and has the same result. Some researchers have successfully used ROA as a proxy of bonus plan such as Barako, Hancock and Izan (2006); and Haniffa and Cooke (2005).

Besides, Zakaria (2011) examines voluntary disclosure and political sensitivity: the case of executive remuneration and investigates the impact of political sensitivity on the quality and quantity of annual bonus plan disclosures in a sample of 400 large UK firms by running two separate regression models. One for disclosure quality while the other for disclosure quantity; it was found that disclosure quantity increases with political sensitivity while disclosure quality reduces as firms become more politically sensitive. The paper finds that managers with excessive remuneration provides high volume but low quality of corporate disclosure is offered by managers with low remuneration (Zakaria, 2011; Masodah, 2007; Rahman, 2005).

H3: Firm's bonus plan is positively associated with its social and environmental disclosure level.

\subsection{Theoretical framework}

Corporate social responsibility is a topic that has gained interest by most researchers from various theoretical perspectives. The most popular perspective is positive accounting theory from Watt and Zimmerman (1986). Positive accounting theory is premised on the neo-classical economic theory. Fundamental to it is a belief in rational choice theory, that is material self-interest usually referred to as opportunity behavior as the basis for all economic activities. Therefore in positive accounting method self interest (opportunistic behavior) is the reason for the choice of accounting method and procedure as well as policy decision (Belkaoui, 2014).

Positive accounting came as an outcome of Jensen's quest for positive accounting approach. Jensen and Meckling (1976) argue that research in accounting was not scientific because the pursuit of accounting profession research had been over floored with normative and definitional researches. Therefore, Jensen and Meckling (1976) hypothesize for the development of positive accounting theory. This explains why those who 
are charged with responsibility and financial accountants react and effects of their reaction (Belkaoui, 2014). In actual fact, the major pursuit of positive accounting approach is to expatiate and predict management selected choice. This is done by analyzing the cost and benefit of financial disclosure in association with various individuals and allocation of relative scare resources within the economy (Belkaoui, 2014).

The theory is based on the proposition that managers, shareholders, and regulators are rational. They attempt to maximize their utility which is directly related to their compensation and their wealth. The factors that influence the world of accounting and test the validity empirically are explained in positive accounting theory (Belkaoui, 2014). It puts across the following hypotheses, namely:

1. Bonus plan,

2. Debt - Equity, and

3. Political cost/ contracting cost.

\subsubsection{Bonus plan hypothesis}

Under this hypothesis, managers, who have accounting incentive or whose remuneration is tied to the firms accounting performance, will tend to manipulate accounting methods and figures to show the accounting performance better than is should be. Managers use different depreciation methods allowing lower profit at the short and higher profit toward the end. Experienced managers will tend to ignore any research and development cost because it will lower current year return affecting their income (Watts \& Zimmerman, 1990; Deegan, 2007; Whittered, 1987; Banwarie, 2011).

H3: Firm's bonus plan is positively associated with its social and environmental disclosure level.

\subsubsection{Debt - Equity hypothesis}

The debt to equity hypothesis states that those who are charged with responsibility will tend to show better profit as similar to the above hypothesis with the intention to have a healthy accounting performance and liquidity position to redeem the interest and principal of the debt in the firm financial structure. The higher the debt to equity level the more managers will tend to use accounting methods and procedures in increasing accounting return (Watts \& Zimmerman, 1990; Christian \& Zuaini, 2012).

\section{H2: Firms leverage is positively associated with corporate social responsibility disclosure level. \\ 2.2.3 Political cost hypothesis}

Under this hypothesis, it assumes that firm will tend to show its return lower by applying various accounting methods and procedures so that the firm does not attract the attention of government, which puts an eye on high return firms (Watts \& Zimmerman, 1986; Christian \& Zuaini, 2012). The firm under positive accounting theory is described in terms of a collection of contract (a nexus of contract). The contract aids individual parties to act to maximize the wealth of the owners (shareholders). Positive accounting holds that firms will seek to minimize the contracting cost (Graffikin, 2007). Watt and Zimmerman (1986) stated that the objective of positive accounting theory is to describe and predict accounting practice of managers. This will enable users of information know which firm publish information about corporate social.

\section{Methodology}

The data for this study were obtained from secondary source which were collected from the audited annual reports as well as accounts of the listed Deposit Money Banks in Nigeria. The population of the study consists of all bank quoted on the floor of Nigeria Stock Exchange as at 2013 there were 15 banks quoted on Nigeria Stock Exchange. The paper is descriptive and highly empirical as it embraces the use of panel regression technique as tool of analysis.

Model Specification:

In order to evaluate prenatal mission or corporate firm and holistic growth, a multiple regression model was built. The model captures the degree of the relationship the explanatory variables exert on the dependent variable.

$\mathrm{CSR}=\beta_{0}+\beta_{1}$ Fsize $_{\text {it }}+\beta_{2} \mathrm{LEV}_{\text {it }}+\beta_{3} \mathrm{ROA}_{\text {it }}+\varepsilon$

Where CSR = corporate social responsibility measured using CSR disclosure index

FSIZE $=$ Firm size measured as the log of total asset

LEV. = Leverage measured as ratio of debt to equity

$\mathrm{ROA}=$ Return on asset measured as profit after tax divided by number of ordinary shares

$\beta_{1}-\beta_{3}$ are the coefficient of the parameter estimate 


\section{Data Presentation And Analysis}

4.1 Operationalization of variables

The variables used in this study are operationalised as shown in the below table:

\begin{tabular}{|c|c|c|c|c|}
\hline $\mathrm{S} / \mathrm{N}$ & Variables & Operational definition & Source & $\begin{array}{l}\text { Apriori } \\
\text { sign }\end{array}$ \\
\hline & $\begin{array}{l}\text { Dependent } \\
\text { variable: }\end{array}$ & & & \\
\hline \multirow[t]{2}{*}{1} & $\begin{array}{l}\text { corporate social } \\
\text { responsibility }\end{array}$ & $\begin{array}{l}\text { corporate social responsibility measured using } \\
\text { CSR disclosure index awareness in financial } \\
\text { statements and its contributions }\end{array}$ & $\begin{array}{l}\text { the Institute of Chartered } \\
\text { Accountants } \\
2004\end{array}$ & $\mathrm{Ve}$ \\
\hline & $\begin{array}{l}\text { Independent } \\
\text { variables: }\end{array}$ & & & \\
\hline 2 & FSIZE & Firm size measured as the log of total asset & Watt \& Zimmerman, 1986. & $+\mathrm{Ve}$ \\
\hline 2 & LEV & Leverage measured as ratio of debt to equity & Belkaoui \& Karpik, 1989. & -ve \\
\hline 3 & ROA & $\begin{array}{l}\text { Return on asset measured as profit after tax } \\
\text { divided by number of ordinary shares }\end{array}$ & $\begin{array}{l}\text { Zakaria, 2011; Rahman, } \\
2005 .\end{array}$ & $+\mathrm{ve}$ \\
\hline
\end{tabular}

Source: Researcher's compliance, 2016.

This section contains the analysis and result presentation of the data collected from the Nigerian Stock Exchange.

Table 1 Descriptive Statistics

\begin{tabular}{|l|l|l|l|l|}
\hline & CSC & Fsize & LEV & ROA \\
\hline Mean & 0.607042 & 658.6081 & 7.246334 & 0.247054 \\
\hline Median & 0.600000 & 5.295735 & 7.019817 & 0.019603 \\
\hline Maximum & 1.000000 & 12090.26 & 9.279750 & 10.03326 \\
\hline Minimum & 0.300000 & -10235.60 & 4.860386 & -2.422443 \\
\hline Std. Dev & 0.165895 & 2700.157 & 1.450070 & 1.267768 \\
\hline Skewness & 1.400021 & 1.212964 & 0.013730 & 6.546755 \\
\hline Kurtosis & 4.067403 & 11.68711 & 1.367243 & 51.82467 \\
\hline \multicolumn{2}{|l}{} & & & \\
\hline Jarque-Bera & 240.6633 & 7.8888837 & 7559.395 \\
\hline Probability & 0.000000 & 0.019362 & 0.000000 \\
\hline Observations & 71 & 71 & 71 \\
\hline Author's computation, 2016 & & & \\
\hline
\end{tabular}

From the table 1 above reveals the descriptive statistics for sample companies. An examination of the result shows that CSC revealed a mean value of 0.60 therefore indicating that on the average only $60 \%$ of sample banking sector disclose their level of engagement in corporate social responsibility activities. This further shows 1.0000 and 0.30000 , explained in the maximum and minimum values respectively. The standard deviation measuring the spread of the distribution stood at a value of 0.166 . The Jarque Bera statistics stood at a value of 26.7 with an associate probability of 0.00 thus, indicates that the variables are normally distributed when measure at critical level. This implies that the possibility of outlier does not exist in the distribution. An additional investigation tested at $5 \%$ critical level.

Table 2: Regression Analysis

\begin{tabular}{|c|c|c|c|c|}
\hline \multirow{2}{*}{\multicolumn{5}{|c|}{\begin{tabular}{|l} 
Dependent Variable: CSC \\
Method: Least Square \\
\end{tabular}}} \\
\hline & & & & \\
\hline Variable & Coefficient & Std.Error & $\mathrm{t}$-Statistic & Prob. \\
\hline $\mathrm{C}$ & 2.838605 & 0.556629 & 5.099637 & 0.0000 \\
\hline Fzise & 0.025164 & 0.006892 & 3.651200 & 0.0014 \\
\hline LEV & -0.299819 & 0.079925 & -3.751239 & 0.0011 \\
\hline ROA & $2.53 \mathrm{E}-05$ & $1.08 \mathrm{E}-05$ & 2.331143 & 0.0293 \\
\hline $\mathrm{AR}(2)$ & 0.200702 & 0.025524 & 7.863209 & 0.0000 \\
\hline R-squared & 0.851367 & Mean dependent var & & 0.620000 \\
\hline Adjusted R-squared & 0.736515 & S.D. dependent var & & 0.175704 \\
\hline S.E of regression & 0.090190 & Akaike infor criterion & & -1.671629 \\
\hline Sum squared resid & 0.178954 & Schwarz criterion & & -0.911634 \\
\hline Log likelihood & 51.43259 & Hannan-Quinn criter & & -1.396839 \\
\hline F-statistic & 7.412693 & Durbin-Watson stat & & 2.075183 \\
\hline Prob(F-statistic) & 0.000013 & & & \\
\hline Author's computation, 201 & & & & \\
\hline
\end{tabular}


The result in table 2 shows that the regression sum of squares (0.090190) is less than the residual sum of squares (0.178954), which indicates that more of the variation in the dependent variable is not explained by the model. It also observed that the F-statistic of 7.413 with the significance probability value of the $\mathrm{F}$ statistics (0.000) is less than 0.05 , which means that the variation explained by the model is not due to chance.

The correlation coefficient has a value of 2.834 , indicates that there is a significant relationship between the prenatal mission of corporate firm and holistic growth. R square, the coefficient of determination, shows that $84 \%$ of the variation in the corporate social responsibility is explained by the model; and the remaining $15 \%$ is accounted for, being captured by the stochastic error term. The Durbin Watson statistics is 2.075

On the bases of individual coefficient, it was observed that firm size, leverage, and return on asset coefficients are: $0.0252,-0.3$, and 2.53 respectively (with $t=3.651,-3.751$, and 2.331 respectively ). This indicates that there is a positive relationship between the firm size and corporate social responsibility; this implies that the size of a firm can impact on the level of corporate social responsibility. Leverage was found to show a negative association with corporate social responsibility. This indicates that a unit change in the debt financing of an organization will lead to a $29 \%$ decrease in the level of engagement in corporate social responsibility. The coefficient value of return on asset revealed a positive relationship, indicating that the level of return on asset of an entity determines the involvement of a firm in corporate social responsibility. Therefore, the null hypothesis should be rejected and the alternative hypothesis accordingly accepted.

Table 3: Heteroskedasticity Test

\begin{tabular}{|l|l|l|l|}
\hline Heteroskedasticity Test: & & & \\
\cline { 1 - 3 } Breusch-Pagan-Godfrey & & & \\
\hline F-statistic & 0.237573 & Prob. F(3,67) & 0.8699 \\
\hline Obs*R-squared & 0.747319 & Prob. Chi-Square(3) & 0.8620 \\
\hline Scaled explained SS & 1.020746 & Prob. Chi-Square(3) & 0.7962 \\
\hline \multicolumn{2}{|l|}{} & \\
\hline
\end{tabular}

The table above reveals the F-statistic and Obs*R-squared values of 0.237573 as well as 0.747319 with p-values of 0.8699 together with 0.8620 respectively show the absence of heteroskedasticity in the model since the F-statistic and Obs*R-squared values and P-values of 0.8699 and 0.8620 are higher than the critical values at $5 \%$ level of significance. Therefore, the researcher now can reach the conclusion that there is never presence of Heteroskedasticity in the model.

\section{Discussion}

From the outcome, firm size was discovered to be positively related with corporate social responsibility. This implies that a firm with large size has the tendency to engage more in corporate social responsibility activities than a small firm. Besides, it validates the theory of positive accounting in relation to political cost hypothesis. Therefore, large firms are politically more responsive than small companies and encounter differential incentives in their selection of accounting concepts and principles that lead them to defer reported returns. The implication is that the managers of those companies consider they are under great deal of political scrutiny as well as political challenges. This necessitates them to disclose their social responsibility via financial reports. This is in line with research work carried out by Watt and Zimmerman (1986).

Leverage, which is the second explanatory variable, was discovered to have a negative association with corporate social responsibility disclosure. This shows that firms with higher leverage than others have the tendency to adhere to strict debt covenant which brings about a restriction in their capacity to spend returns or available financial resources on corporate social duties. This is in line and constant with the discovery of Belkaoui and Karpik (1989). However, Ahmed, Hazzan and Mohammad (2003) researched on determinants of environmental reporting in Malaysia found that leverage and corporate social responsibility have a positive relationship. Moreover, return on asset has a positive association with corporate social responsibility. The implication is that companies that carry out and involve in corporate social responsibility may have greater returns as compared with companies which do not involve in corporate social responsibility activities. This is consistent with the discovery of Zakaria (2011) and Rahman (2005).

\section{Conclusion And Recommendation}

Having gone through various available research works in relation to disclosure of corporate social responsibility using positive accounting theory as a theoretical framework; the paper discovered that there are mixed conclusions. Positive accounting hypothesis is based on the principle of shareholders wealth. The empirical outcome, under positive accounting as related to the firms' features of bonus plan, is positively related to corporate social responsibility disclosure. This means that if managers are rewarded for their effective performances, according to stock exchange rate or accounting profits, they would be tempted to increase 
accounting earnings or engage in intrinsic transactions to maximize their wealth by disclosing their corporate social responsibility in annual reports. Managers who are charged with fiduciary duties would engage in this act in as much, more CSR disclosure may result to better performance and be rewarded.

Therefore, this paper recommends that firm should make provision for management compensation. This occurs when firms provide adequate welfare of management through incentives in order to encourage them to disclose corporate social responsibility activities. Hypothesis two addresses the issue of leverage. It was discovered that leverage has a negative relationship with corporate social responsibility disclosure level. The implication is that a firm with a high leverage adheres to strict debt covenant. This hinders the firm to engage in CSR exercise. Therefore, the paper submits that further research should explore to explain the inconsistency of previous outcomes in addressing relationship between leverage and corporate social responsibility. On the basis of firm size, the paper discovered empirical evidence to corroborate the hypothesis that public visibility, which is proxy with size, has a positive relationship with corporate social responsibility disclosure level. Finally, the finding confirms the political cost hypothesis that companies with higher visibility in the political arena. This calls for the attention of government and serves as government - imposed wealth transfers. Therefore, this paper recommends that firms should have incentives in order to make more voluntary disclosures, in an effort to minimize political charges.

\section{Reference}

[1] Ajide, F. M., \& Adetunji, A. A. (2014). The effects of corporate social responsibility activity disclosure on corporate profitability: Empirical evidence from Nigerian commercial banks. IOSR Journal of Economics and Finance, 2(6), $17-25$.

[2] Ahmed, Z., Hazzan, S., \& Mohammad, J. (2003). Determinants of environmental reporting in Malaysia. International Journal of Business Studies, 11(1), 69-90.

[3] Amole, B. B., Adebiyi, S. O., \& Awolaja, A. M. (2012).Corporate Social Responsibility and Profitability of Nigeria Banks - A Casual Relationship. Research Journal of Finance and Accounting, 3(1): 6-17.

[4] Banwarie, U. R. (2011). The relationship between ownership structure and CSR disclosure. Unpublished doctoral thesis, Erasmus National University

[5] Belkaoui, A. R. (2014). Accounting theory. $5^{\text {th }}$ edition: USA, Learning Solution Specialty Publications Ltd.

[6] Belkaoui, A., \& Karpik, P. G. (1989). Determinants of the corporate decision to disclose social information. Accounting, Auditing and Accountability Journal, 2(1), 36-51.

[7] Branco, M. C., \& Rodrigues, L. L. (2008). Factors influencing social responsibility disclosure by Portuguese companies. Journal of Business Ethics, 83(1), $685-701$.

[8] Christina, T. S.,\& Zuaini, I. (2012). Corporate social and environmental disclosure: A positive accounting theory view point. International Journal of Business and Social Science, 3(9)

[9] Cormier, D., \& Magnan, M. (2003). Environmental reporting management: A European perspective. Journal of Accounting and Public Policy, 22, 43-62.

[10] Deegan, C. M. (2007). Financial accounting theory. Australia: McGraw-Hill.

[11] Deegan, C., \& Unerman, J. (2005). Financial accounting theory. London, UK: McGraw Hill

[12] Deegan, C., \& Gordon, B. (1996). A study of the environmental disclosure practices of Australian corporations. Accounting and Business Research 26(3), 187-199.

[13] European Commission (2006). Promoting a European framework for corporate social responsibility, Brussels. Green paper, 32.

[14] Gray, R. H., Owen, D. L., \& Adams, C. (1996). Accounting and accountability, changes and challenges in corporate social and environmental reporting. Prentice Hall, Heme Hempstead.

[15] Graffikin, M. J. R. (2007). Accounting research and theory: The age of neo-empiricism. Australasian Accounting and Business and Finance Journal, 1(1), 1-19.

[16] Gray, R. H., Javad, M. ,Power, D., \& Sinclair, C. D. (2001). Social and environmental disclosures and corporate characteristics, a research note and extension. Journal of Business Finance \& Accounting, 28, 327-356.

[17] ICAN. (2014). Study text: Management, government and ethics. United Kingom: Emile Woolf International Bracknell Enterprise \& Innovation Hub.

[18] Jensen M. C., \& Meckling W. (1976). Theory of the firm, managerial behavior, agency cost, and ownership structure. Journal of Financial Economics 11, 5-50.

[19] KPMG. (2005). World class transactions survey: Insights into creating shareholder value

[20] Hibbit, C. (2003). External environmental disclosure and reporting by large European companies: An economic, social and political analysis of managerial behaviour. Unpublished Doctoral thesis. Limperg Instituut, Netherland.

[21] Maignan, I., \& Ferrell, O. C. (2004). Corporate social responsibility and marketing: an integrative framework. Journal of Academic and management Science, 32(1), 3-19.

[22] Magnan, M., Nadeau, C., \& Cormier, D. (1999). Earnings management during antidumping investigations: analysis and implications. Canadian Journal of Administrative Sciences, 16(2), 149-162.

[23] Masodah (2007). Praktik perataan laba sektor industri perbankan dan lembaga keuangan lainnya dan faktor- faktor yang mempengaruhinya. PESAT, 2,16-23.

[24] Musa, A. F. (2010). Determinants of corporate social responsibilities in the Nigerian listed Deposit Money Banks. International Journal of Economics, Business and Finance, 1(10), $11-15$.

[25] Ness, K., \& Mirza, A. (1991). Corporate social disclosure: A note on a test of agency theory. British Accounting Review, 23, 211-217.

[26] Obi, D. (2013). CRS: 8 banks spend \#1.9bn to make social impact. This Business day News paper. www.businessdayonline.com

[27] Olayinka, M. U., \& Temitope, O. F. (2011). Corporate social responsibility and financial performance in developing economies: The Nigerian experience. New Orleans, New Orleans International Academic Conference, 815-824.

[28] Orij, R. (2007). Corporate social disclosures and accounting theories: an investigation. European Accounting Association, Lisbon,

[29] Rahman, A., \& Widyasari, K. N. (2008). The analysis of company characteristic toward CSR disclosure: Empirical evidence of manufacturing companies listed in JSX. Journal Auditing dan Akuntansi Indonesia, 12(1), 25-35. 
[30] Robins, R. (2011). Does corporate social responsibility increase profit? Business ethics. The magazine of corporate social responsibility. www.business-ethics.com

[31] Sarumpaet, S. (2005). The relationship between environmental performance and financial performance of Indonesian companies. Journal Akuntansi dan Keuangan, 7(2), 89-96.

[32] Servaes, H., \& Tamayo, A. (2013). The impact of corporate social responsibility on firm value: The role of customer awareness. Management Science, 59(5), 1045 - 1061.

[33] Stefan, C. G., Georgeta, V., \& Diana, D. (2015). An empirical research on the relationship between corporate social responsibility rating and U.S. listed companies 'value. Journal of Economic Studies and Research, 25(1), 10 - 11.

[34] Visser, W., Matten, D., Pohl, M., \& Tolhurust, N. (2010). The A to Z of corporate social responsibility. Chichester: John Wiley \& Sons.

[35] Watts, R. L., \& Zimmerman, J. L. (1990). Positive accounting theory: A ten year perspective. The Accounting Review, 65(1), $131-156$.

[36] Watts, R. L., \& Zimmerman, J. L. (1986). Positive accounting theory. London: Prentice-Hall.

[37] Zakaria, I. (2011). Voluntary disclosure and political sensitivity: The case of executive remuneration. Working Paper. Essex Business School. University of Essex. 